\title{
PEMILIHAN LAYANAN ANGKUTAN JALAN UNTUK PARIWISATA DI KABUPATEN PASURUAN
}

\author{
Nailie Azizah \\ Magister Perencanaan Wilayah Dan Kota, Universitas Diponegoro Semarang, \\ nay.azizah@gmail.com
}

\begin{abstract}
ABSTRAK
Pengembangan pariwisata sebagai salah satu pemanfaatan ruang wilayah di Kabupaten Pasuruan menjadi salah satu sektor prioritas dalam menumbuhkan ekonomi baru. Pariwisata sebagai kegiatan yang sifatnya diskrit telah membentuk pergerakan wisatawan yang dinamis, sehingga adanya permintaan sarana transportasi yang fleksibel dan adanya kepastian dari aspek waktu dan biaya. Berkembangnya layanan angkutan jalan online menjadi salah satu alternatif sarana angkutan jalan bagi wisatawan untuk perjalanannya selain layanan angkutan non daring. Hal ini menunjukkan bahwa permintaan angkutan jalan untuk kegiatan pariwisata sangat tinggi, sehingga perlunya penelitian guna mengetahui kecenderungan pemilihan layanan angkutan jalan daring dan non daring untuk kegiatan pariwisata di Kabupaten Pasuruan. Penelitian ini bertujuan untuk mengetahui preferensi wisatawan terhadap layanan angkutan jalan daring dan non daring untuk perjalanan wisata di Kabupaten Pasuruan. Metode penelitian menggunakan pendekatan stated preference dengan pengambilan data secara accidental sampling dan menganalisis data melalui analisis regresi dan perhitungan binomial logit. Hasil analisis dan perhitungan secara logit binomial menunjukkan besar nilai probabilitas pada pemilihan layanan angkutan jalan daring moda minibus terhadap layanan angkutan jalan non daring dengan moda mobil pribadi, angkutan shuttle dan angkutan travel sebesar 0,$63 ; 0,83$; dan 0,90 . Hal ini menjelaskan bahwa kecenderungan wisatawan memilih layanan angkutan jalan daring sebagai angkutan pariwisata lebih besar daripada layanan angkutan jalan non daring. Hasil penelitian ini sejalan dengan langkah pemerintah daerah setempat yang mulai menyediakan layanan angkutan pariwisata yang berbasis aplikasi. Merujuk dari hasil penelitian ini nantinya dapat mengadopsi dari layanan angkutan pariwsata yang sudah ada dengan melakukan pembaharuan pada aplikasi tersebut. Namun, ketersediaan layanan angkutan pariwisata tersebut perlu untuk disosialisasikan kepada masyarakat sebagai pengguna nantinya, sehingga layanan tersebut dapat bekerja optimal.
\end{abstract}

Kata kunci : Layanan angkutan jalan, pariwisata, daring, non daring, preferensi.

\begin{abstract}
Tourism development as one of the utilization of regional space in Pasuruan Regency is one of the priority sectors in growing a new economy. Tourism as a discrete activity has formed a dynamic tourist movement, resulting in the demand for flexible transportation facilities and certainty in terms of time and cost. the development of online road transportation services is an alternative means of road transportation for tourists to travel in addition to non-online transportation services. This shows that the demand for road transport for tourism activities is very high, so that research is needed to determine the trends in choosing online and non-online road transport services for tourism activities in Pasuruan Regency. This study aims to determine tourist preferences for online and non-online road transportation services for tourist trips in Pasuruan Regency. The research method uses a stated preference approach by taking data by accidental
\end{abstract}


sampling and analyzing data through regression analysis and binomial logit calculations This study used a stated preference approach method with accidental sampling data collection and analyzed the data through regression analysis and binomial logit calculation. The result of regression analysis and binomial logit calculation shows the probability value in choosing online road transport services for minibus mode of nononline road transport services by private car, shuttle and travel transportation are 0.63; 0.83; and 0.90. This explains that the tendency of tourists to choose online road transportation services as tourism transportation is greater than non-online road transportation services. The results of this study are in line with the steps of the local government which began to provide application-based tourism transportation services. Referring to the results of this research, later it can be adopted from existing tourism transportation services by updating the application. However, the availability of tourism transportation services needs to be socialized to the community as users later, so that these services can work optimally.

Keywords: road transport services, tourism, preferences.

\section{PENDAHULUAN}

Perkembangan sektor pariwisata telah berpengaruh secara signifikan terhadap kehidupan sosial, ekonomi, budaya dan lingkungan (Kim et al., 2013). Salah satunya melalui pembangunan pariwisata lokal untuk meningkatkan lapangan kerja dan pendapatan nasional (Szivas et al., 2003). Perkembangan sektor pariwisata sebagai salah satu bentuk pemanfaatan ruang di daerah, tidak lepas dari ketersediaan infrastruktur transportasi sebagai faktor pendukung aksesibilitasnya. Pengembangan dan penyediaan infrastruktur transportasi merupakan syarat utama pada pengembangan pariwisata di setiap daerah. Sorupia (2005) berpendapat bahwa pentingnya transportasi dalam pengembangan pariwisata, karena tanpa adanya transportasi, pariwisata tersebut tidak bisa berkembang .

Penyediaan sarana prasarana transportasi yang memadai sebagai fasilitas untuk mobilitas wisatawan merupakan persyaratan mendasar dalam pariwisata (Tóth \& Dávid, 2010). Layanan sarana transportasi jalan saat ini mulai berkembang melalui kemajuan teknologi informasi yang terlihat dari munculnya berbagai aplikasi layanan jasa transportasi daring di Kabupaten Pasuruan. Ketersediaan layanan ini menjadi alternatif wisatawan untuk melakukan perjalanan wisata selain angkutan jalan non daring seperti kendaraan pribadi, angkutan shuttle maupun angkutan travel.
Ketersediaan layanan moda angkutan jalan pariwisata sebagai sarana transportasi yang perlu difasilitasi oleh pemerintah daerah sebagai upaya pembangunan pariwisata yang terintegrasi dengan transportasi. Pengembangan sarana angkutan jalan di Kabupaten Pasuruan khususnya untuk kegiatan pariwisata perlu diupayakan agar terintegrasi dengan destinasi tujuan wisata yang mayoritas dihubungkan dengan jalur jalan.

Penelitian sebelumnya yang mendasari penelitian ini diantaranya oleh Al Abror dan Risdianto (2019) mengenai layanan transportasi untuk pariwisata berfokus pada rute perjalanan wisatawan di Kabupaten Kerinci, penelitian Adyanandha, Haviz, dan Riani (2019) mengidentifikasi faktor yang berperan dominan pada preferensi masyarakat tentang pemilihan tranportasi taksi berbasis aplikasi di Kota Bandung serta penelitian Basuki dan Setiadi (2015) tentang potensi angkutan pariwisata di Daerah Istimewa Yogyakarta dengan mengkaji penggunaan angkutan umum untuk perjalanan wisata di daerah tersebut.

Layanan transportasi sebagai bagian dari sistem jaringan dalam pariwisata sangat penting untuk sistem pergerakan wisatawan. Oleh karena itu sarana transportasi jalan sebagai salah satu komponen aksesibilitas pada pengembangan pariwisata perlu dikembangkan sesuai dengan perannya dalam memberikan kemudahan wisatawan untuk mobilitasnya yang dinamis. 
Pengembangan layanan angkutan jalan yang sesuai dengan minat wisatawan menjadi hal yang menarik untuk diteliti dengan mengetahui preferensi mereka pada layanan angkutan jalan daring dan non daring yang untuk pariwisata di Kabupaten Pasuruan. Layanan angkutan jalan yang menjadi obyek pilihan diantaranya layanan angkutan jalan daring dengan moda minibus berkapasitas hingga 10 orang, dan layanan angkutan jalan non daring yang terdiri dari moda mobil pribadi, angkutan shuttle dan angkutan travel. Moda tersebut merupakan kendaraan yang umumnya digunakan oleh masyarakat Ketika melakukan perjalanan wisata. Tujuan dari penelitian ini untuk mengetahu kecenderungan wisatawan memilih layanan angkutan jalan daring dan non daring pada kegiatan pariwisata di Kabupaten Pasuruan.

\section{KAJIAN LITERATUR \\ Karakteristik Wisatawan}

Wisatawan merupakan orang yang melakukan kegiatan wisata ke suatu tempat dengan tujuan berwisata dan tidak dengan tujuan mencari uang atau bekerja (Tunjungsari, 2018). Karakteristik wisatawan, pola kunjungan, motivasi perjalanan ke suatu obyek wisata berbeda untuk masing-masing individu (Smith \& Stephen., 1989). Hal tersebut bergantung pada motivasi tujuan kunjungan dari individu masing-masing. Karakteristik wisatawan sebagai pelaku pergerakan berpengaruh terhadap preferensi mereka pada pemilihan moda transportasi yang akan digunakan. Karakteristik sosio ekonomi wisatawan (Beerli \& Martín, 2004; Hardiani \& Amril, 2017) meliputi : (1) Jenis kelamin; (2) Usia; (3) Daerah asal responden; (4) Tingkat Pendidikan; (5) Status Perkawinan; (6) Status Pekerjaan; (7) Pendapatan per bulan

\section{Karakteristik Perjalanan Wisatawan}

Wisatawan yang melakukan perjalanan dan kunjungan ke beberapa obyek seringkali merencanakannya secara individu terkait waktu dan biaya perjalanan wisatanya. Pemilihan destinasi kunjungan wisata ditentukan oleh motivasi wisatawan berkunjung ke obyek wisata tersebut. Perjalanan wisata individu memiliki karakteristik sendiri, tentunya setiap individu berbeda pola kunjungan dan perjalanan wisatanya. Lau \& McKercher (2006) dalam penelitiannya menjelaskan bahwa kunjungan dan perjalanan wisata seseorang seringkali ipengaruhi oleh beberapa faktor diantaranya: (1) Faktor manusia yang terdiri dari motivasi kunjungan, pihak perjalanan, tipe perjalanan wisatawan (individu atau massal); (2) Faktor fisik (geomorfologi tujuan); (3) Faktor perjalanan yaitu tujuan utama atau sekunder, transportasi yang digunakan (terkait pemilihan moda); (4) Faktor waktu yaitu lamanya waktu kunjungan di tujuan wisata, total durasi perjalanan.

Hal lain yang mendasari seseorang melakukan perjalanan dan kunjungan wisata di suatu daerah adalah adanya obyek baru yang menjadi daya tarik untuk dikunjungi. Selain itu daya tarik beberapa destinasi wisata yang pernah dikunjungi sebelumnya oleh wisatawan, masih menjadi alternatif tujuan kunjungan untuk melihat beberapa perubahan yang mungkin terjadi pada obyek wisata tersebut.

\section{Pemilihan Moda Transportasi}

Le-Klähn \& Hall (2015) dalam penelitiannya menjelaskan bahwa pola kunjungan wisatawan di daerah memiliki keterkaitan erat dengan pemilihan moda transportasi. Pemilihan moda merupakan tahapan yang penting dalam melakukan perjalanan wisata seseorang karena berkaitan erat dengan pergerakan wisatawan di suatu obyek tujuan wisata. Pemilihan moda transportasi pada perjalanan wisata pengaruhi oleh beberapa faktor yakni daerah asal pengunjung, maksud motivasi kunjungan, frekuensi kunjungan, teman perjalanan, persepsi kemudahan yang terkait dengan pemilihan angkutan, lama kunjungan, waktu kunjungan, dan besar biaya perjalanan.

Pada penelitian ini pemilihan angkutan untuk kegiatan pariwisata difokuskan pada layanan angkutan jalan daring dan non daring. Hal ini dikarenakan destinasi wisata yang berada di Kabupaten Pasuruan ini mayoritas aksesibilatasnya 
melalui jalur jalan (darat). Selain itu fenomena perkembangan layanan angkutan jalan daring di Kabupaten Pasuruan saat ini menjadi salah satu alternatif angkutan penumpang yang seringkali digunakan oleh wisatawan selain angkutan jalan non daring seperti angkutan shuttle, mobil pribadi, dan angkutan travel. Penelitian Adyanandha et al. (2019) menjelaskan bahwa diantara faktor-faktor berikut yakni kemudahan, keselamatan, pengalaman, tarif, waktu tunggu pemesanan, kenyamanan dan waktu tempuh, yang berpengaruh dalam pemilihan moda adalah faktor kemudahan. Faktor kemudahan berkaitan dengan akses untuk mendapatkan moda transportasi yang salah satunya berhubungan dengan ketersediaan armada setiap waktu. Pada kondisi ini atribut moda transportasi yakni waktu operasional kendaraan menjadi salah satu pertimbangan masyarakat untuk memilih angkutan online, karena termasuk dalam faktor kemudahan.

Pemilihan layanan moda angkutan jalan seringkali dipengaruhi oleh beberapa aspek yakni waktu dan biaya perjalanan. Selain itu kebutuhan terhadap angkutan jalan pada kegiatan pariwisata sebagai alat angkutan menuju destinasi tujuan wisata merupakan hal dasar yang penting dalam perkembangan sektor pariwisata, karena setiap pergerakan wisatawan bergantung kepada alat angkutan untuk mobilitasnya.

Berkembanganya layanan angkutan jalan saat ini memberi pengaruh kepada wisatawan dalam menggunakan alat angkutan untuk perjalanan wisatanya. Layanan angkutan jalan daring yang berkembang pesat di berbagai wilayah menjadi salah satu alternatif angkutan jalan selain angkutan jalan non daring yang umumnya digunakan selama ini. Pada penelitian Abror \& Risdianto (2019) menjelaskan tentang permintaan layanan transportasi pariwisata yang didasarkan pada rute pergerakan wisatawan ketika melakukan perjalanan wisata di Kabupaten Kerinci. Hasil penelitian menunjukkan pentingnya penyediaan layanan tranportasi sebagai pendukung kegiatan pariwisata berdasarkan rute pergerakan wisatawan.

Pemilihan angkutan perjalanan oleh individu dipengaruhi persepsi mereka dengan mempertimbangkan aspek waktu dan biaya perjalanan. Seseorang akan mengutamakan angkutan jalan yang dapat memperpendek waktu tempuh, waktu tunggu, ketersediaan moda tiap saat (waktu operasional), dan biaya perjalanan yang pasti untuk jarak yang akan ditempuh. Persepsi seseorang banyak dipengaruhi oleh beberapa faktor (Miro, 2005) diantaranya faktor karakteristik pengguna, karakteristik perjalanan, serta karakteristik fasilitas moda transportasi. Pada perjalanan wisata, tiga faktor tersebut mempengaruhi seorang wisatawan untuk pemilihan moda angkutan untuk kegiatan wisata yang sifatnya dinamis dan fleksibel. Wisatawan akan memilih layanan angkutan jalan yang dapat mewadahi pergerakannya yang fleksibel dan memberikan kepastian.

\section{Zona II dan Zona III Pengembangan Pariwisata Kabupaten Pasuruan}

Kabupaten Pasuruan merupakan salah satu daerah di Provinsi Jawa Timur yang berada di segitiga emas jalur distribusi Surabaya-Malang-Banyuwangi. Wilayah ini mengalami perkembangan yang pesat terutama di sektor pariwisata dan sektor transportasi. Pembangunan infrastruktur jalan tol yang sudah mulai beroperasi memberi dampak terhadap perkembangan pariwisata lokalnya. Berkembanganya destinasi tujuan wisata baru di berbagai wilayah Kabupaten Pasuruan mampu menarik pengunjung dalam dan luar daerah untuk melakukan perjalanan wisata ke daerah ini, apalagi dengan adanya TNBTS Desa Wonokitri yang menjadi Kawasan strategis pariwisata nasional sebagai magnitude bagi pertumbuhan wisata lokal disekitarnya.

$$
\text { Perkembangan prasarana }
$$

transportasi tersebut belum dapat memberikan layanan yang optimal untuk sektor pariwisata. Ketersediaan angkutan jalan untuk kegiatan pariwisata dirasa masih minim. Pemerintah Kabupaten Pasuruan menyediakan sistem informasi angkutan pariwisata sebagai upaya untuk memberikan kemudahan masyarakat yang berkunjung ke obyek wisata di daerah ini. Akan tetapi sistem layanan angkutan ini hanya beroperasi di satu titik saja yang berada di zona IV, sedangkan 
perkembangan pariwisata daerah yang mengalami pertumbuhan cepat banyak di zona II dan zona III yang merupakan jalur distribusi ke wilayah Malang. Hal ini terlihat dari keberadaan obyek wisata TSI II Prigen, Cimory land, Wisata Kebun Kurma, Kebun Raya Purwodadi, Agrowisata Bhakti alam, Kebun wisata Pak Budi, Taman dayu festival, TNBTS Desa Wonokitri dan masih banyak obyek lainnya.

\section{Teknik Stated Preferences}

Stated preference merupakan suatu pendekatan dengan cara menyampaikan pertanyaan pilihan (option) yang berupa suatu hipotesa untuk dinilai oleh responden. Pernyataan preferensi tersebut tentang suatu alternatif yang dibandingkan dengan alternatif yang lain. Pendekatan tersebut memungkinkan diperolehnya data yang dapat menerangkan tanggapan perilaku perjalanan terhadap situasi sistem transportasi yang baru (situasi hipotesis).

Teknik ini menggunakan pertanyaan berkaitan dengan responden wisatawan dalam memberikan pilihannya terhadap situasi yang berbeda dan berubah. Setiap wisatawan ditanya tentang responnya apabila mereka dihadapkan pada tiga skenario pemilihan layanan angkutan jalan untuk kegiatan pariwisata dalam kondisi yang sebenarnya untuk mengetahui preferensi mereka terhadap pilihan yang ditawarkan.

Hasil survei digunakan sebagai input untuk model yang bertujuan memprediksi perilaku masa depan, di mana validitas dan keandalan kesimpulan dari model ini menjadi perhatian utama (Louviere, Hensher dan Swait (2000) dalam (Petrik et al., 2016).

\section{METODE PENELITIAN}

Penelitian ini menggunakan kuesioner dengan pendekatan metode stated preferences, dimana pengambilan sampel dilakukan secara accidental sampling kepada pengunjung obyek wisata di zona II dan zona III pariwisata Kabupaten Pasuruan.

Survey pendahuluan dilakukan untuk mengetahui kondisi eksisting dari atribut perjalanan pada fasilitas moda transportasi daring dan non daring yang beroperasi di lokasi penelitian. Berdasarkan data survey tersebut kemudian disusun desain kuesioner dengan 3 skenario pilihan moda angkutan jalan melalui perubahan pada atribut waktu dan biaya. Responden mengisi kuesioner tersebut dengan teknik stated preference melalui choice experiment dengan 5 pilihan skala semantik.

Data hasil survey nantinya akan dianalisis melalui analisis regresi dan perhitungan binomial logit untuk mendapatkan nilai probabilitas pemilihan layanan angkutan jalan daring dan non daring oleh wisatawan.

\section{PEMBAHASAN}

Karakteristik wisatawan yang melakukan perjalanan wisata pada obyek wisata di zona II dan zona III pariwisata Kabupaten Pasuruan berdasarkan analisis karakteristik sosio ekonomi.

Dari hasil data survey kuesioner menunjukkan bahwa mayoritas wisatawan yang melakukan perjalanan wisata di Kabupaten Pasuruan adalah wisatawan rombongan keluarga dengan rentang usia dewasa yang rata-rata berpendidikan tinggi dengan tingkat penghasilan berkisar $\mathrm{Rp}$. 3.000.000,00 sampai dengan Rp. $5.000 .000,00$ perbulannya.

wisatawan yang datang bergender laki-laki dan perempuan, mayoritas pengunjung obyek tersebut adalah keluarga dengan rentang usia dewasa, berpendidikan tinggi, bekerja dan tergolong berpenghasilan sangat tinggi per bulannya. Hal ini digambarkan pada gambar 1.1 berikut ini. 

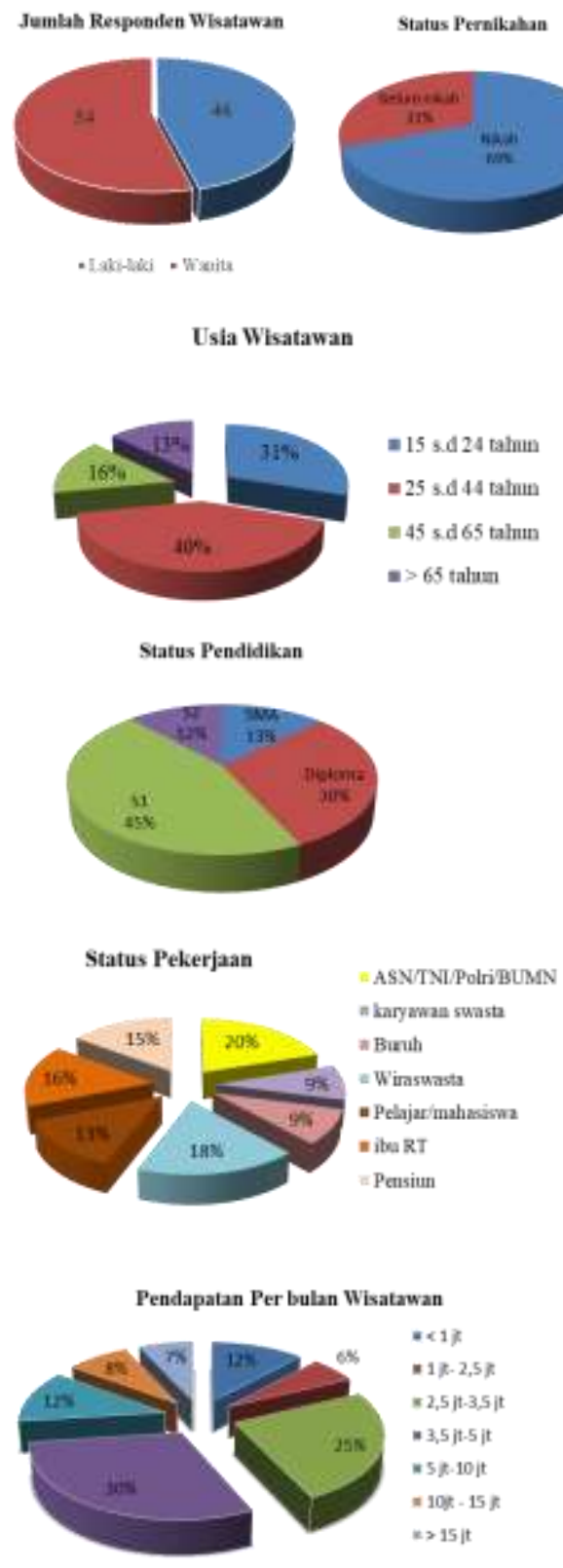

Gambar 1

Karakteristik Sosio Ekonomi Wisatawan Di Kabupaten Pasuruan

Sumber : Hasil Analisis Penulis, 2020

Wisatawan yang melakukan perjalanan wisata menuju destinasi wisata di Kabupaten Pasuruan, berdasarkan data kuesioner yang telah didistribusikan kepada 100 responden diperoleh hasil karakteristik perjalanan wisatawan di Kabupaten Pasuruan seperti yang tergambarkan pada gambar 2 .
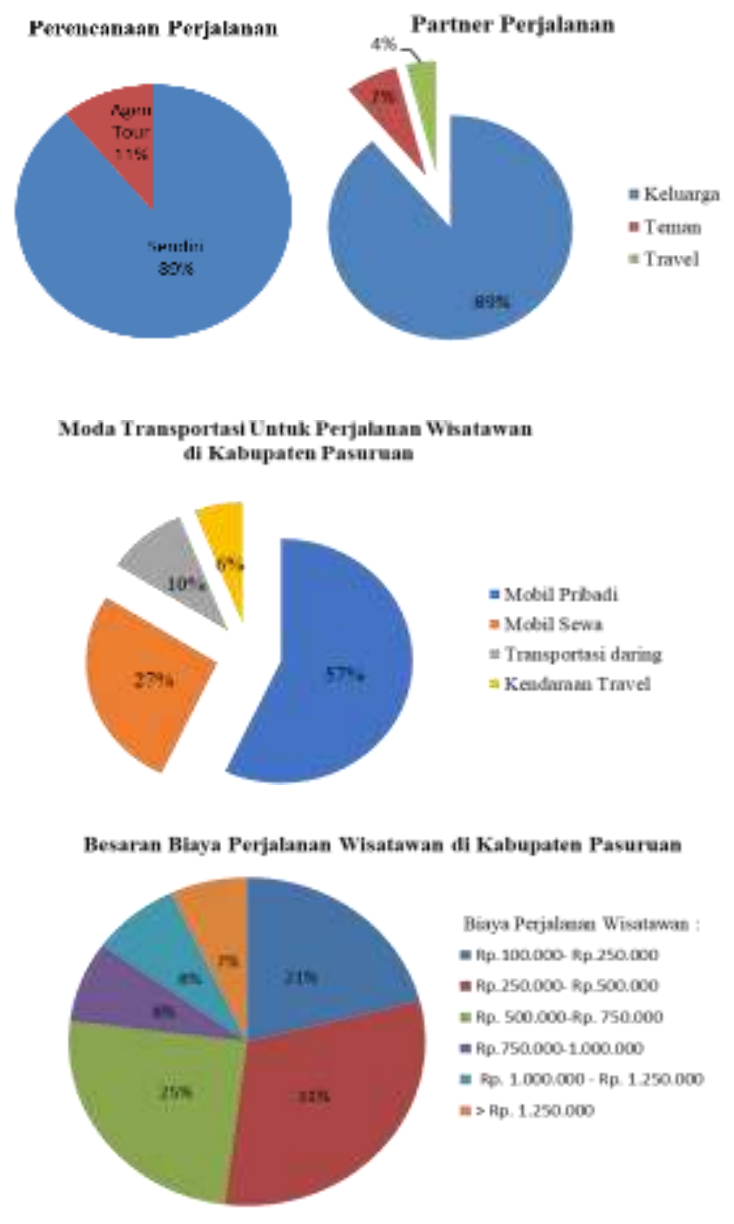

Gambar 2

Karakteristik Perjalanan Wisatawan Sumber : Hasil Analisis Penulis, 2020

Berdasarkan hasil pengolahan data tentang karakteristik perjalanan wisatawan di Kabupaten Pasuruan menunjukkan bahwa mayoritas wisatawan merencanakan perjalanan wisatanya sendiri ke obyek wisata di Kabupaten Pasuruan dengan membawa anggota keluarga sebagai teman dalam perjalanannya. Mayoritas wisatawan dari dalam wilayah Kabupaten Pasuruan lebih banyak menggunakan moda angkutan mobil pribadi sebagai alat angkutan mereka menuju destinasi tujuan wisata dengan biaya perjalanan yang dikeluarkan berkisar antara Rp.250.000,00 sampai Rp. $500.000,00$.

Karakrteristik perjalanan tersebut berkaitan dengan kunjungan wisata yang dilakukan wisatawan ke beberapa obyek wisata yang menjadi destinasi tujuan wisatanya. Berdasarkan hasil kuesioner 
tersebut diperoleh hasil tentang karaktertistik kunjungan wisatawan di Kabupaten Pasuruan seperti yang terlihat pada gambar 3 dibawah.

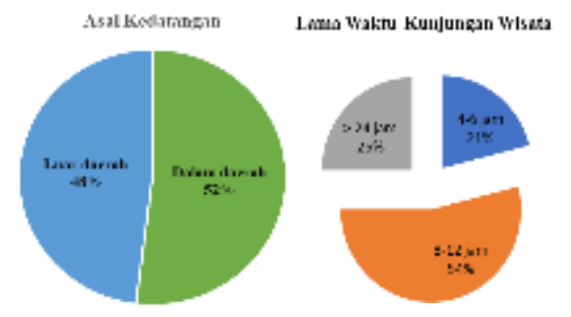

Waktu Kunjungan
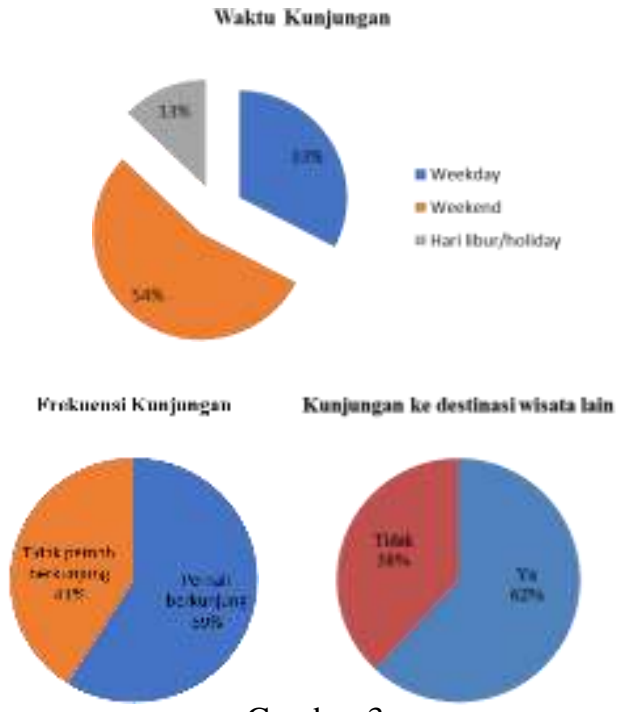

Gambar 3

Karakteristik Kunjungan Wisatawan Sumber : Hasil Analisis Penulis, 2020

Pada gambar 3 diketahui bahwa wisatawan yang melakukan perjalanan wisata ke Kabupaten Pasuruan mayoritas wisatawan dalam daerah yang sebelumnya sudah pernah mengunjungi obyek wisata yang sama dan mereka melakukan perjalanan tersebut dengan tujuan obyek wisata lebih dari satu. Waktu kunjungan yang banyak dilakukan oleh wisatawan adalah di akhir pekan yakni hari sabtu dan minggu dengan lama kunjungan mayoritas 8 sampai 12 jam atau halfday.

Berdasarkan identifikasi terhadap karakteristik responden, perjalanan dan kunjungan wisatawan dapat disimpulkan bahwa wisatawan yang berwisata di Kabupaten Pasuruan memiliki pergerakan yang dinamis, sehingga membutuhkan alat angkutan yang fleksibel dan ada kepastian untuk menuju destinasi tujuan wisata yang dikehendaki. Berkaitan dengan penggunakan angkutan jalan yang beragam saat ini, melalui penelitian ini dilakukan analisis terhadap preferensi wisatawan dengan tiga skenario pemilihan layanan angkutan jalan daring dan non daring melalui perubahan terhadap nilai waktu yang terdiri dari waktu tempuh, waktu tunggu moda, waktu operasional kendaraan dan nilai biaya perjalanan.

Analisis Kecenderungan Pemilihan Angkutan Jalan Daring Minibus dan Non daring (Mobil pribadi,Angkutan Shuttle, dan Angkutan Travel)

Berdasarkan hasil survey kuesioner preferensi wisatawan diperoleh data yang kemudian dianalisis dengan metode regresi untuk memperoleh persamaan utilitas ,yakni:

$Y_{\text {minibus-mobil }}=0,71129+(-0,00006 * \Delta$ biaya

perjalanan $)+(-0,09333 * \Delta$

waktu tempuh)-(-0,10772*

$\Delta$ waktu tunggu $)+(0,10431 *$

$\Delta$ waktu operasional)... (1)

$Y_{\text {minibus-shuttle }}=\mathbf{1 , 5 8 5 2}+\mathbf{( - 0 , 0 0 0 0 4} *$

$\Delta$ biaya perjalanan $)+(-$

$0,0503 * \Delta$ waktu tempuh)

$+(-0,0467 * \Delta$ waktu

tunggu $)+(-0,0658 * \Delta$

waktu operasional)

$Y_{\text {minibus-travel }}=2,2054+(-0,00004 * \Delta$ biaya

perjalanan $)+(-$

$, 0603 * \Delta$ waktu tempuh $)+(-$

$, 0335 * \Delta$ waktu tunggu $)+(-$

$0,1365 * \Delta$ waktu operasional)

Dari persamaan tersebut, dilakukan perhitungan binomial logit sesuai dengan persamaan di bawah, sehingga diperoleh kurva probabilitas seperti pada gambar 4 .

$$
\begin{aligned}
& \mathrm{P}(\mathrm{D})_{\text {Minibus }}=\frac{\exp Y}{\exp Y+1} \\
& \mathrm{P}(\mathrm{ND})_{\text {moda } X 1,2,3}=\frac{1}{\exp Y+1}
\end{aligned}
$$



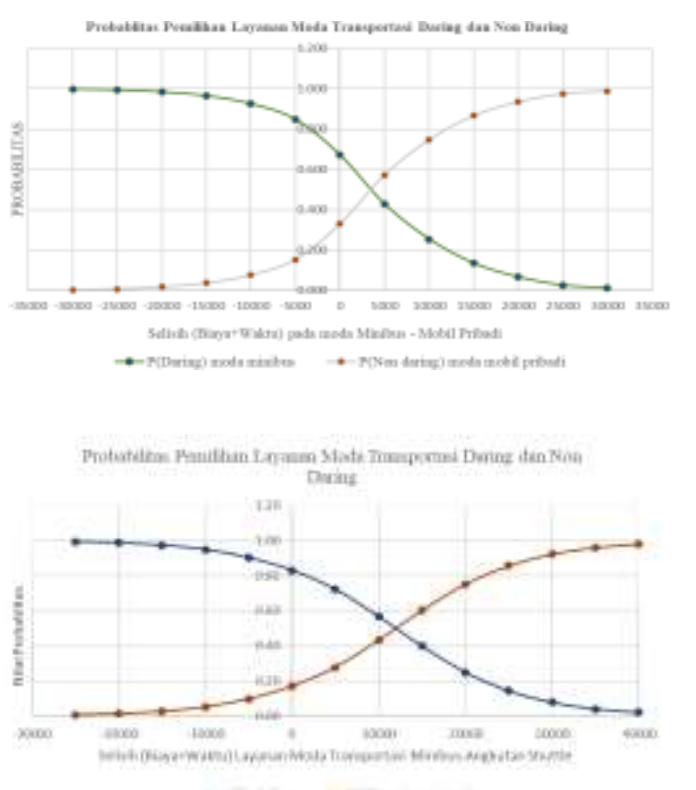

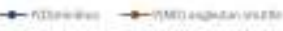

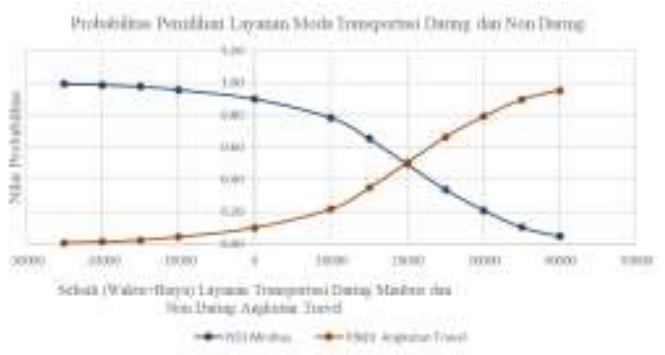

Gambar 4

Kurva Probabilitas Pemilihan Layanan Angkutan Jalan Daring Dan Non Daring Untuk Kegiatan Pariwisata Di Kabupaten Pasuruan

Sumber : Hasil Analisis Penulis, 2020

Kurva probabilitas dari perhitungan binomial logit di atas menjelaskan bahwa nilai probabilitas pemilihan layanan angkutan jalan daring dengan moda minibus terhadap layanan angkutan jalan non daring dengan moda mobil pribadi, angkutan shuttle dan angkutan travel sebesar 0,$67 ; 0,83$; dan 0,90. Perubahan pada selisih (waktu+biaya) mempengaruhi preferensi wisatawan dalam memilih layanan angkutan jalan untuk kegiatan pariwisata. Berdasarkan nilai tersebut disimpulkan bahwa wisatawan yang melakukan aktifitas wisata di Kabupaten Pasuruan cenderung banyak memilih menggunakan layanan angkutan jalan daring sebagai alat angkutan pariwisata untuk menuju destinasi tujuan wisata di Kabupaten
Pasuruan daripada layanan angkutan jalan non daring. Kecenderungan pemilihan layanan angkutan jalan daring lebih besar sebab pola pergerakan wisatawan di Kabupaten Pasuruan dari hasil identifikasi terhadap karakteristik kunjungan dan perjalanannya menunjukkan pola yang dinamis, sehingga kebutuhan layanan angkutan jalan untuk mewadahi pergerakan yang dinamis tersebut harus lebih fleksibel. Selain itu kegiatan pariwisata yang sifatnya diskrit memunculkan kunjungan wisatawan yang mayoritas pada akhir pekan, namun kunjungan tersebut juga dilakukan pada waktu-waktu tertentu sehingga wisatawan membutuhkan angkutan jalan yang memiliki kepastian dari segi ketersediaan armada setiap saat serta biaya perjalanan yang pasti.

\section{PENUTUP}

Berdasarkan hasil pembahasan di atas dapat disimpulkan bahwa kecenderungan pemilihan layanan angkutan jalan berbasis daring lebih besar dari pada layanan angkutan jalan non daring untuk kegiatan pariwisata di Kabupaten Pasuruan. Hasil penelitian ini ternyata sejalan dengan program pemerintah daerah setempat yang telah meluncurkan aplikasi sistem informasi angkutan pariwisata yang berbasis daring pada Oktober 2019.

Pada aplikasi ini menyediakan layanan angkutan pariwisata yang beroperasi pada akhir pekan dengan rute perjalanan di sekitar destinasi wisata KSPN TNBTS Desa wonokitri, sedangkan untuk destinasi wisata yang berada di area zona II dan zona III belum terlayani karena sistem informasi angkutan pariwisata berbasis daring baru beroperasi di titik poin zona IV pengembangan pariwisata di Kabupaten Pasuruan yang berada di Kecamatan Pasrepan. Berdasarkan hasil penelitian disarankan untuk menyediakan layanan angkutan jalan daring dengan mengadopsi aplikasi dari pemerintah daerah yang telah tersedia dengan melakukan beberapa pembaharuan dalam aplikasi tersebut dan melakukan sosialisasi ketersediaan aplikasi layanan angkutan jalan daring untuk kegiatan pariwisata 
yang diwadahi oleh pemerintah daerah Kabupaten Pasuruan melalui Sistem Informasi Angkutan Pariwisata tersebut.

\section{REFERENSI}

Adyanandha, R., Haviz, M., \& Riani, W. (2019). Faktor - Faktor yang Menentukan Preferensi Masyarakat Kota Bandung Terhadap Moda Transportasi Taksi Berbasis Aplikasi Online. Prosideing Ekonomi, 55-61.

Basuki, I., \& Setiadi, A. (2015). Potensi angkutan umum pariwisata di daerah istimewa yogyakarta. Jurnal Transportasi, 15(2), 135-142.

Beerli, A., \& Martín, J. D. (2004). Tourists' characteristics and the perceived image of tourist destinations: A quantitative analysis A case study of Lanzarote, Spain. Tourism Management, 25(5), 623636.

https://doi.org/10.1016/j.tourman.200 3.06.004

Hardiani, H., \& Amril. (2017). Socioeconomic determinants of tourism trips by Jambi residents. Jurnal Perspektif Pembiayaan Dan Pembangunan Daerah, 4(4), 219 230. https://onlinejournal.unja.ac.id/JES/article/view/38 01/2779

Hayat, B., Abror, A., \& Risdianto, O. (2019). Layanan Transportasi dalam Pengembangan Pariwisata di Kabupaten Kerinci Transportation Services of Kerinci Tourism Development. Jurnal Manajemen Transportasi Dan Logistik, 06(02), 125-134. https://doi.org/10.25292/j.mtl.v6i2.30 6

Kim, K., Uysal, M., \& Sirgy, M. J. (2013). How does tourism in a community impact the quality of life of community residents? Tourism Management, 36, 527-540. https://doi.org/10.1016/j.tourman.201 2.09 .005

Lau, G., \& McKercher, B. (2006). Understanding Tourist Movement Patterns in a Destination: A GIS Approach. Tourism and Hospitality Research, 7(1), 39-49. https://doi.org/10.1057/palgrave.thr.6 050027

Le-Klähn, D. T., \& Hall, C. M. (2015). Tourist use of public transport at destinations - a review. Current Issues in Tourism, 18(8), 785-803. https://doi.org/10.1080/13683500.201 4.948812

Miro, F. (2005). Perencanaan

Transportasi untuk Mahasiswa, Perencana, dan. Praktisi. Erlangga.

Petrik, O., De Abreu e Silva, J., \& Moura, F. (2016). Stated preference surveys in transport demand modeling: Disengagement of respondents. Transportation Letters, 8(1), 13-25. https://doi.org/10.1179/1942787515Y .0000000003

Smith, S. L. J., \& Stephen., D. (1989). Tourism Analysis: A Handbook. Longman Scientific \& Technical. Sorupia, E. (2005). Rethinking the role of transportation in tourism. Eastern Asia Society for Transportation Studies, 5(January 2005), 1767-1777.

Szivas, E., Riley, M., \& Airey, D. (2003). Labor mobility into tourism attraction and satisfaction. Annals of Tourism Research, 30(1), 64-76. https://doi.org/10.1016/S01607383(02)00036-1

Tóth, G., \& Dávid, L. (2010). Tourism and accessibility: An integrated approach. Applied Geography, 30(4), 666-677. https://doi.org/10.1016/j.apgeog.2010 .01 .008

Tunjungsari, K. R. (2018). Karakteristik dan Persepsi Wisatawan Mancanegara di Kawasan Sanur dan Canggu, Bali. Jurnal Pariwisata Terapan, 2(2), 108. https://doi.org/10.22146/jpt.43178

\section{BIODATA PENULIS}

Nailie Azizah, mahasiswa program pascasarjana Magister Perencanaan Wilayah Dan Kota Universitas Diponegoro Semarang. Bekerja sebagai staf verifikasi dan perencanaan di Dinas Perumahan dan Kawasan Permukiman Pemerintah Kabupaten Pasuruan. 